\title{
ANALISIS TINGKAT KEPUASAN PETANI JAGUNG TERHADAP PELAYANAN LEMBAGA PEMASARANNYA DI KECAMATAN LUBUK PINANG KABUPATEN MUKOMUKO
}

\author{
Analysis of Satisfaction Level Corn Farmers to Their Marketing \\ Institution Services in Subdistrict of Lubuk Pinang District of \\ Mukomuko \\ Irvan Diyahya'), Ketut Sukiyono²) dan Redy Badrudin'2) \\ 1)Alumni dan ${ }^{2)}$ Staf Pengajar pada Jurusan Sosial Ekonomi Pertanian, \\ Fakultas Pertanian, Universitas Bengkulu
}

\begin{abstract}
This research was conducted in Sumber Makmur village, Lubuk Pinang subdistrict Mukomuko District from in March 2015 by surveyed 92 corn farmers as samples. This study is aimed at investigating the performance and the benefit of an attribute services marketing institutions agribusiness in support of corn in kabupaten mukomuko and estimating satisfaction level of corn farmers to marketing institutions services in support corn agribusiness in Kabupaten Mukomuko. The purpose of the first analyzed by Importance Performance Analysis (IPA) method and the purpose of the second analyzed by Customer Satisfaction Index (CSI) method. From IPA results, it can be drawn conclusions that marketing institution 1 services aspects that need to be improved and are considered important for farmers are fast service, right and always respond to help the farmers of corn, the accuracy of scales and willingness to respect and serving officers and by prioritising the needs of farmers. Then the marketing institution 2 services aspects that need to be improved and be considered important for farmers are communicating information the quality of corn desired consumers to farmers, the ability to communicate from the officers and openness and honesty in giving information service. Corn growers were satisfied with marketing services institution 1 with CSI of 70,65 \%, and to marketing institution 2 with CSI of 72,21\%.
\end{abstract}

Keywords: Corn, Marketing, IPA, CSI, Satisfaction.

\section{PENDAHULUAN}

Keberadaan lembaga pemasaran jagung sangat penting demi pengembangan agribisnis jagung dari aspek pemasaran. Survai di Kecamatan Lubuk Pinang yang merupakan salah satu wilayah penghasil jagung terbesar di Kabupaten Muko-muko menunjukkan bahwa ada dua lembaga pemasaran pada wilayah tersebut. Kedua toke (pedagang pengumpul desa) ini sebagai 
pedagang yang membeli atau mengumpulkan jagung pipil dari tangan petani. Masing-masing toke (pedagang pengumpul desa) yaitu atas nama bapak Ponimin (lembaga pemasaran 1) dan bapak Kustur (lembaga pemasaran 2) merupakan toke yang aktif pada tingkat desa sehingga kedua toke inilah sebagai lembaga pemasaran terpilih yang masing-masing akan dinilai oleh petani-petani yang berhubungan langsung dengan toke-toke tersebut.

Pelayanan dari lembaga pemasaran terbagi atas beberapa dimensi yang masing-masing dimensi memiliki item-item atribut layanan. Atribut-atribut inilah yang dinilai oleh petani jagung untuk melihat tingkat kepuasan yang diawali dengan indetifikasi kinerja dan kepentingan masing - masing atributnya. Artinya untuk melihat tingkat kepuasan petani jagung terhadap lembaga pemasarannya, tahap awal yang dilakukan adalah menilai tingkat kinerja dan tingkat kepentingan dari atribut masing-masing layanan lembaga pemasaran tersebut apakah atribut layanan kinerja dari lembaga pemasaran baik ataukah kategori lainnya dan juga atribut-atribut layanan tersebut dianggap penting atau tidak bagi petani. Oleh sebab itu, tujuan penelitian ini adalah (1) untuk mengetahui atribut-atribut mana sajakah yang dianggap penting oleh petani dan perlu ditingkatkan oleh lembaga pemasarannya dan (2) Selanjutnya dari penilaian tingkat kinerja dan tingkat kepentingan tersebut akan bisa diukur tingkat kepuasan masing-masing petani terhadap layanan lembaga pemasaran yang bersangkutan.

\section{METODOLOGI PENELITIAN}

\section{Penentuan Lokasi Penelitian}

Metode yang digunakan dalam penentuan lokasi penelitian adalah dengan menggunakan metode Sampling Kelompok Dua Tahap (Two Stage Cluster Sampling). Langkahnya adalah dengan memilih Kecamatan Lubuk Pinang sebagai kecamatan penelitian dengan pertimbangan sebagai sentra jagung terbesar di Kabupaten Mukomuko. Selanjutnya yaitu memilih satu desa sampel yang diteliti yaitu desa Sumber Makmur dengan didasarkan bahwa desa ini paling berpotensi dalam hal usahatani jagung.

\section{Metode Pengumpulan Data}

Penelitian ini menggunakan data primer dan data sekunder. Data primer merupakan data yang didapat dari sumber pertama baik dari individu atau perseorangan seperti hasil dari wawancara atau hasil pengisian kuisioner yang biasa dilakukan oleh peneliti (Umar, 2003 dalam Listiawati, 2010). Data sekunder yang digunakan dalam penelitian ini yaitu data yang diperolah dari studi pustaka, internet dan literatur instansi atau dinas terkait yang terdiri dari

46 | Irvan Diyahya, Ketut Sukiyono dan Redy Badrudin, Analisis Tingkat ... 
data demografi, monografi, luas lahan, dan data lain yang berkaitan dengan penelitian.

\section{Metode Penentuan Responden}

Penentuan jumlah sampel petani untuk menilai lembaga pemasaran menggunakan sampling kelompok (Cluster Sampling). Di Desa Sumber Makmur ada petani yang berhubungan dengan toke atas nama Bapak Ponomin dan petani yang berhubungan dengan toke atas nama bapak dimana masing-masing populasi yaitu 215 jiwa dan 148 jiwa. Kemudian masing-masing kelompok akan dibagi atas 3 strata berdasarkan luas lahan dimana dari sumber data bahwa luas lahan terluas yaitu 2,50 ha dan yang tersempit adalah 0,50 ha. Peneliti disini membaginya dalam 3 strata luas lahan sehingga diperoleh rentang interval yaitu sebesar 0,66 . Dengan demikian ada 3 strata yang sama untuk masing-masing cluster penelitian. Terlebih dahulu perlu ditentukan besar varians setiap strata pada masing-masing cluster. Kemudian jumlah sampel masing-masing cluster menggunakan rumus stratifikasi yang dikutip dari (Scheaffer et al, 1990 dalam Sukiyono, 2013). Tabel 1 menyajikan jumlah sampel yang diambil pada masing masing klaster. Selanjutnya penentuan sampel yakni secara acak dengan dengan nomor undian untuk selanjutnya dilakukan wawancara.

Tabel 1. Jumlah Sampel Setiap Strata Pada Masing-masing Cluster Penelitian

\begin{tabular}{lcccc}
\hline \multirow{2}{*}{ Strata (ha) } & \multicolumn{2}{c}{ Cluster 1 } & \multicolumn{2}{c}{ Cluster 2 } \\
\cline { 2 - 5 } & Populasi (N) & Sampel (n) & Populasi (N) & Sampel (n) \\
\hline Sempit & 25 & 5 & 16 & 5 \\
Sedang & 114 & 23 & 91 & 30 \\
Luas & 76 & 15 & 41 & 14 \\
\hline \multicolumn{1}{c}{ TOTAL } & $\mathbf{2 1 5}$ & $\mathbf{4 3}$ & $\mathbf{1 4 8}$ & $\mathbf{4 9}$ \\
\hline
\end{tabular}

Sumber: Kerangka Sampling (2014) diolah (2015)

\section{Metode Analisis Data}

\section{Importance Performance Analisis (IPA)}

Rangkuti (2006) menyebutkan bahwa IPA merupakan alat analisis tingkat kepentingan dan kinerja dari suatu produk/jasa. Analisa ini digunakan untuk menjawab permasalahan mengenai sejauh mana tingkat kepuasan petani terhadap pelayanan dari lembaga pemasaran. Pengukuran dihitung menggunakan skala likert 5 tingkat untuk mengukur tingkat kepentingan yaitu sangat penting (5), penting (4), cukup penting (3), kurang penting(2) dan tidak penting (1). Skala Likert juga digunakan untuk mengukur tingkat kierja yaitu sangat baik (5), baik (4), cukup baik (3), kurang baik (2), tidak baik (1). 
Tahapan dalam metode Importance Performance Analysis mengikuti saran yang diajukan oleh Supranto (2001). Pertama, menghitung rata - rata kinerja $\left(\bar{X}_{i}\right)$ dan kepentingan $\left(\bar{Y}_{i}\right)$ dari seluruh pelanggan. Rata - rata kinerja dan kepentingan dari seluruh pelanggan dihitung dengan rumus sebagai berikut:

$$
\bar{X}_{i}=\frac{\sum_{n=1}^{n} X_{i n}}{n} \quad \text { dan } \quad \bar{Y}_{i}=\frac{\sum_{n=1}^{n} Y_{i n}}{n}
$$

dimana $n$ adalah jumlah responden.

Kedua, menghitung Tingkat Kesesuaian (TKi) antara tingkat kinerja dan kepentingan atau harapan. Tki dihitung dengan rumus sebagai berikut:

$$
T K_{i}=\frac{\bar{Y}_{i}}{\bar{X}_{i}} \times 100 \%
$$

dimana $X_{i}$ adalah skor kinerja atribut ke $\mathrm{i}$, dan $Y_{i}$ adalah skor kepentingan atribut ke i.

Ketiga, menghitung rata - rata kinerja $(\overline{\bar{X}})$ dan kepentingan $(\overline{\bar{Y}})$ dari seluruh atribut. Rata - rata kinerja dan kepentingan seluruh atribut dihitung dengan rumus sebagai berikut:

$$
\overline{\bar{X}}=\frac{\sum_{i=1}^{K} \bar{X}_{i}}{K} \text { dan } \overline{\bar{Y}}=\frac{\sum_{i=1}^{K} \bar{Y}_{i}}{K}
$$

dimana $\mathrm{K}$ adalah Banyaknya atribut yang dapat mempengaruhi kepuasan pelanggan.

Nilai $\overline{\bar{X}}$ dan $\overline{\bar{Y}}$ digunakan sebagai pasangan koordinat titik atribut yang memposisikan suatu atribut terletak dimana pada diagram kertesius. Penjabaran dari diagram kartesius dapat dapat dilihat pada gambar berikut:

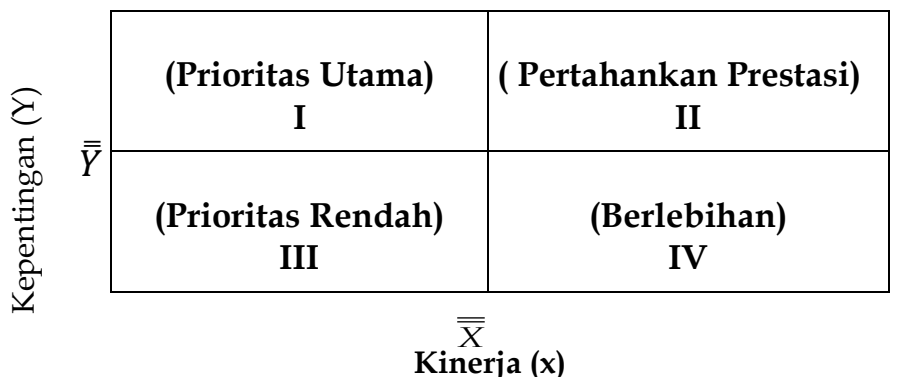

Gambar 1.

Diagram Kartesius (Nasution, 2001)

\section{Kuadran I (Prioritas Utama)}

Kuadaran ini merupakan wilayah yang membuat aspek dengan tingkat kepentingan tinggi tetapi memiliki tingkat kinerja rendah, 
sehingga mengecewakan petani. Aspek-aspek yang masuk pada kuadran ini harus ditingkatkan kinerjanya dan menjadi prioritas dari lembaga.

\section{Kuadran II (Pertahankan Prestasi)}

Kuadran ini menunjukan atribut-atribut yang dianggap sangat penting oleh petani jagung dan telah dilaksanakan oleh lembaga terkait. Aspek-apsek yang masuk pada kuadran ini harus tetap dipertahankan dan harus terus dikelola dengan baik.

\section{Kuadran III (Prioritas Rendah)}

Kuadran ini merupakan wilayah yang memuat atribut dengan tingkat kepentingan dan tingkat kinerja rendah. Aspek-aspek yang temasuk dalam kuadran ini dirasakan kurang penting oleh petani dan pelaksanaanya dinilai kurang baik. Namun lembaga juga tetap perlu mewaspadai, mencermati dan mengontrol setiap aspek pada kuadran ini, karena tingkat kepentingan petani dapat berubah seiring meningkatnya kebutuhan.

\section{Kuadran IV (Berlebihan)}

Kuadran ini menunjukan atribut-atribut yang dianggap kurang penting oleh petani, namun lembaga telah melaksanakannya dengan baik, sehingga dianggap berlebihan.

\section{Customer Satisfaction Index (CSI)}

Menurut Startford (2004), metode pengukuran (CSI) meliputi tahap-tahap: (1) Menghitung Importance weighting factors (faktor kepentingan terbobot), (2) Menghitung Weighted Score (skor terbobot), (3) Menghitung weighted total (total terbobot), (4) Menghitung satisfaction index (indeks kepuasan), yaitu weighted total dibagi skala maksimal yang digunakan (skala maksimal 5), kemudian dikalikan $100 \%$. Kepuasan tertinggi dicapai bila CSI menunjukan 100\%. Rentang kepuasan berkisar dari 0-100\%. Menurut Simamora (2004), untuk membuat skala linear numeric, petama-tama kita cari rentang skala (RS) dengan mengurangkan persentase tertinggi dan persentase terendah lalu dibagi 5 (skala likert). Dengan demikian, kriteria kepuasanya adalah (a) $0 \% \leq$ CSI $\leq 20 \%$ (tidak puas), (b) $21 \% \leq$ CSI $\leq 40 \%$ (kurang puas), (c) $41 \% \leq \mathrm{CSI} \leq 60 \%$ (cukup puas), (d) $61 \% \leq \mathrm{CSI} \leq 80 \%$ (puas), dan (e) $81 \% \leq$ CSI $\leq 100 \%$ (sangat puas) 


\section{HASIL DAN PEMBAHASAN}

\section{Karakteristik Lembaga Pemasaran Jagung dan Petani Jagung}

Jagung pipil yang telah dipanen dan ditleser oleh petani langsung dijual kepada toke-toke yang ada di desa ini. Berdasarkan hasil penelitian ada 2 toke yang hingga tahun 2015 senantiasa berperan sebagai lembaga pemasaran ditingkat desa yaitu atas nama bapak Ponimin dan Bapak Kustur. Untuk lembaga pemasaran 1 telah memulai usahanya sejak tahun 2006 hingga saat ini, sedangkan lembaga pemasaran 2 telah memulai usahanya sejak 2011 hingga saat ini. Banyak pedagang pengumpul yang telah ada namun hingga saat ini hanya kedua pedagang ini yang tetap bertahan dengan jumlah pelanggan (petani) yang konsisten. Kedua toke ini membeli jagung pipil dari petani dengan harga yang sama yaitu Rp 3000/kg,-nya. Rantai selanjutnya, kedua lembaga pemasaran ini sama-sama menjual jagung ke pedagang pengumpul tingkat kecamatan di daerah padang namun berbeda tempat penjualannya. Kemudian pedagang pengumpul tingkat kecamatan ini sama-sama menjual jagung mereka pada beberapa pedagang pengecer namun berbeda dalam hal jumlah dan pedagang pengecernya. Masing-masing pedagang pengecer langsung menjual jagungnya pada konsumen-konsumen mereka.

Sebagian besar petani berada pada kategori muda dengan rentang umur rata-rata 24 hingga 45,33 tahun yaitu sebanyak 49 petani atau sebesar 53,26\%. Pada usia muda, seseorang cenderung mempunyai kemampuan yang baik dalam berpikir dan bertindak untuk merencanakan suatu kegiatan usahatani. Dari segi pekerjaan tergambar bahwa pekerjaan pokok petani sebagian besar adalah sebagai petani jagung, walaupun disisi lain terkadang mereka juga sebagai petani-petani yang mengusahakan berbagai komditi seperti tanaman palawija, padi, kacang-kacangan dan sebagainya. Hasil menunjukkan bahwa tingkat pendidikan petani masih relatif rendah, dimana sebagian besar pendidikan adalah 6 tahun atau setingkat dengan Sekolah Dasar dengan persentase terbesar $60.87 \%$. Dengan dibuktikan dari penelitian Bahua (2014) bahwa ada hubungan yang kuat antara tingkat pendidikan formal terhadap kualitas usahatani dengan nilai koefisien korelasi sebesar 0,96. Penelitiaannya menyimpulkan dengan semakin tinggi tingkat pendidikan maka seorang petani cenderung memiliki jiwa responsif terhadap adopsi teknologi baru sehingga mendorong mutu usahatani mereka. Dari segi pengalaman berusahatani jagung bahwa sebagian besar responden memiliki pengalaman usahatani antara 3 sampai 10 tahin lebih dengan dibuktikan dari jumlah jiwa terbanyak yaitu 47 responden atau sebesar 51,09\%. Hasil penelitian Bahua mendukung bahwa ada hubungan yang kuat antara pengalaman berusahatani jagung dengan mutu/kompetensi berusahatani yaitu dengan nilai korelasi sebesar 0,96. Dia menyimpulkan bahwa petani responden yang telah memiliki banyak berpengalaman ini akan lebih berhati-hati dalam menerima suatu hal baru.

50 | Irvan Diyahya, Ketut Sukiyono dan Redy Badrudin, Analisis Tingkat ... 
Selanjutnya luas kepemilikan lahan responden yaitu antara 1,17 sampai 1,83 hektar sebanyak 53 dari 92 responden dengan persentase terbesar yaitu 57,61 \%. Hal ini menandakan bahwa luas lahan yang dimiliki mereka berada pada kategori sedang. Hasil penelitian Bahua mendukung bahwa ada hubungan yang cukup kuat antara luas kepemilikan lahan dengan kompetensi berusahatani jagung dengan dibuktikan nilai koefisien korelasi sebesar 0,97. Dia menyebutkan bahwa dengan luas lahan usahatani yang cukup seta kepemilikan sendiri memudahkan petani dalam mengambil keputusan untuk melakukan usahatani jagung hibrida. Dari segi jumlah tanggungan keluarga persentase terbesar adalah jumlah tanggungan keluarga yang berkisar antara 3 dan 4 yaitu sebesar $60,87 \%$. Jumlah tanggungan keluarga yang banyak mempunyai keuntungan dalam penggunaan tenaga kerja jika anggota keluarga tepat berada pada usia yang produktif maka akan sangat membantu petani dalam usahatani mereka.

\section{Analisa Tingkat Kinerja (Performance), Kepentingan (Importance) 0}

Seperti yang telah dijelaskan di atas, tingkat kesesuaian merupakan hasil perbandingan antara menghitung skor kinerja dan skor kepentingan. Yola dan Budianto (2013) mengatakan bahwa tingkat kesesuaian digunakan untuk menentukan skala prioritas layanan dan prioritas perbaikan mencapai kepuasan pelanggan. Berdasarkan perhitungan TKi pada Tabel 2. diperoleh nilai rata-rata tingkat kesesuaian Lembaga Pemasaran 1 (LP 1) adalah sebesar sebesar 113,35\% dan Lembaga Pemasaran 1 (LP 1) sebesar 107,76 \%. Angka angka ini menujukkan bahwa apa yang dilakuakn oleh LP 1 maupun LP 2 telah sesuai dengan apa ayng diinginkan oleh pelangganya.

Data Tabel 2 juga menunjukkan bahwa atribut mampu menampung berapapun jagung yang dihasilkan dan akan dijual oleh petani merupakan atribut yang memiliki kesesuaian terendah pada LP 1. Artinya, atribut ini masih belum sesuai dengan harapan pelanggan sehingga perlu adanya perbaikan dan perhatian dari LP 1. Sementara pada LP2, kelengkapan sarana pengepakkan merupakan atribut yang harus diperbaiki secara terus menerus agar sesuai dengan keinginan konsumen atau pelanggannya. Lebih lanjut sesuai dengan dikatakan oleh Indriwinangsih dan Sudaryanto (2007), jika presentase 80 - 100\% maka kesesuaian tersebut dapat dikatakan kinerja dari masing-masing atribut telah dapat memenuhi harapan dari konsumen tetapi masih perlu dilakukan perbaikan lagi. Presentase $>100 \%$ dapat dikatakan kinerja atribut telah melebihi dengan harapan konsumen. 
Tabel 2 Hasil perhitungan rata-rata penilaian tingkat kepentingan dan tingkat kinerja untuk dua lembaga pemasaran

\begin{tabular}{|c|c|c|c|c|c|c|}
\hline \multirow{2}{*}{ Aspek-aspek Pelayanan (Atribut) } & \multicolumn{2}{|c|}{ LP 1} & \multicolumn{4}{|c|}{ LP 2} \\
\hline & $(\bar{X})$ & $(\bar{Y})$ & TKi & $(\bar{X})$ & $(\bar{Y})$ & Tki \\
\hline \multicolumn{7}{|l|}{ Tangible (fisik) } \\
\hline 1. Kelengkapan sarana pengepakkan & 3.74 & 4.07 & 108,82 & 3.94 & 3.59 & 91,12 \\
\hline 2. Peralatan selama proses transaksi & & & & & & \\
\hline $\begin{array}{l}\text { (kalkulator, buku, pena, alat timbang dan } \\
\text { lain-lain) }\end{array}$ & 3.63 & 4.14 & 114,05 & 3.80 & 4.08 & 107,37 \\
\hline $\begin{array}{l}\text { 3. Alat komunikasi yang dimiliki oleh petugas } \\
\text { (telepon dan handphone) }\end{array}$ & 3.58 & 3.88 & 108,38 & 3.90 & 3.88 & 99,49 \\
\hline $\begin{array}{l}\text { 4. Adanya alat transpotasi yang digunakan } \\
\text { untuk memasarkan produk }\end{array}$ & 3.77 & 4.28 & 113,53 & 4.18 & 3.88 & 92,82 \\
\hline \multicolumn{7}{|l|}{ Reliability (keandalan) } \\
\hline $\begin{array}{l}\text { 1. Menyampaikan informasi kualitas jagung } \\
\text { yang diinginkan konsumen kepada petani }\end{array}$ & 3.02 & 3.12 & 103,31 & 2.90 & 3.96 & 136,55 \\
\hline 2. Kemampuan berkomunikasi dari petugas & 3.56 & 3.88 & 108,99 & 3.43 & 4.22 & 123,03 \\
\hline $\begin{array}{l}\text { 3. Kemampuan petugas dalam membantu } \\
\text { memberikan solusi atas keluhan petani } \\
\text { dalam hal pemasaran jagung }\end{array}$ & 3.26 & 3.91 & 119,94 & 3.22 & 3.71 & 115,22 \\
\hline \multicolumn{7}{|l|}{ Responsivenes (Kesigapan/tanggap) } \\
\hline $\begin{array}{l}\text { 1. Pelayanan yang diberikan cepat, tepat dan } \\
\text { selalu tanggap membantu petani jagung }\end{array}$ & 3.40 & 4.12 & 121,18 & 3.45 & 3.49 & 101,16 \\
\hline \multicolumn{7}{|l|}{ Assurance (Kepastian/ Jaminan) } \\
\hline $\begin{array}{l}\text { 1. Mampu menampung berapapun jagung } \\
\text { yang dihasilkan dan akan dijual oleh petani }\end{array}$ & 3.44 & 3.30 & 95,93 & 3.39 & 3.65 & 107,67 \\
\hline $\begin{array}{l}\text { 2. Ketepatan waktu dalam membayar jagung } \\
\text { yang dibelinya }\end{array}$ & 3.53 & 4.37 & 123,80 & 4.08 & 3.90 & 95,59 \\
\hline $\begin{array}{l}\text { 3. Harga beli yang pantas/sesuai terhadap } \\
\text { jagung yang dibeli dari petani }\end{array}$ & 3.93 & 4.49 & 114,25 & 3.94 & 4.04 & 102,54 \\
\hline $\begin{array}{l}\text { 4. Kekuratan timbangan saat melakukan } \\
\text { penimbangan jagung }\end{array}$ & 3.44 & 4.47 & 129,94 & 3.78 & 4.12 & 108,99 \\
\hline \multicolumn{7}{|l|}{ Empathy (Perhatian) } \\
\hline $\begin{array}{l}\text { 1. Kesediaan untuk menghargai dan melayani } \\
\text { serta mengutamakan kebutuhan petani }\end{array}$ & 3.35 & 4.16 & 124,18 & 3.35 & 3.67 & 109,55 \\
\hline $\begin{array}{ll}\text { 2. Keterbukaan dan kejujuran dalam } \\
\text { memberikan pelayanan informasi }\end{array}$ & 3.63 & 3.70 & 101,93 & 3.20 & 4.29 & 134,06 \\
\hline Rata-rata & 3.52 & 3.99 & 113,35 & 3.61 & 3.89 & 107,76 \\
\hline
\end{tabular}

Sumber: data promer diolah (2015)

Keterangan: LP (lembaga pemasaran), X (tingkat kinerja), Y (tingkat kepentingan), dan TK = tingkat kesesuaian 
Tingkat kinerja dari item-item atribut secara keseluruhan relatif lebih kecil dari pada tingkat kepentingan. Pada kasus lembaga pemasaran 1, hanya ada 1 aspek (atribut) layanan yang memiliki nilai kinerja yang lebih tinggi dibandingkan dengan nilai kepentingannya yaitu aspek "Mampu menampung berapapun jagung yang dihasilkan dan akan dijual oleh petani" dengan nilai skor rata-rata 3,44 >3,30. Sedangkan pada kasus lembaga pemasaran 2 ada beberapa aspek (atribut) layanan dengan nilai kinerja yang lebih tinggi dibandingkan nilai kepentingannya diantaranya aspek "Kelengkapan sarana pengepakkan" dengan nilai 3,94 > 3,59, aspek "Alat komunikasi yang dimiliki oleh petugas" dengan nilai 3,90 >3,88, aspek "Adanya alat transpotasi yang digunakan untuk memasarkan produk" dengan nilai 4,18>3,88 dan aspek "Ketepatan waktu dalam membayar jagung yang dibelinya" dengan nilai 4,08 $>$ 3,90. Perbedaan hasil dari pengukuran untuk dua pelayanan lembaga pemasaran ini disebabkan karena penilaian yang berbeda dari petani terhadap lembaga pemasaran yang bersangkutan. Agar pengukuran tingkat kepentingan dan tingkat kinerja dari atribut-atribut ini bisa lebih bermakna, disajikan diagram Kartesius untuk memperoleh gambaran mengenai atribut mana yang menjadi prioritas utama, prioritas dipertahankan, rendah ataupun berlebihan:

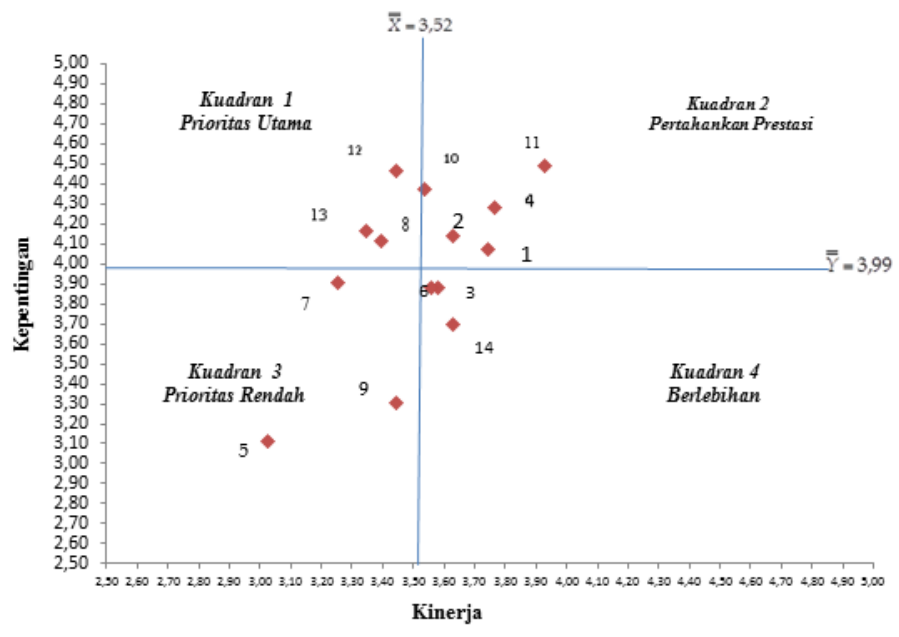

Gambar 2.

Diagram Kartesius Untuk Pengukuran Importance dan Performance Layanan Lembaga Pemasaran 1 (An Bapak Ponimin) 


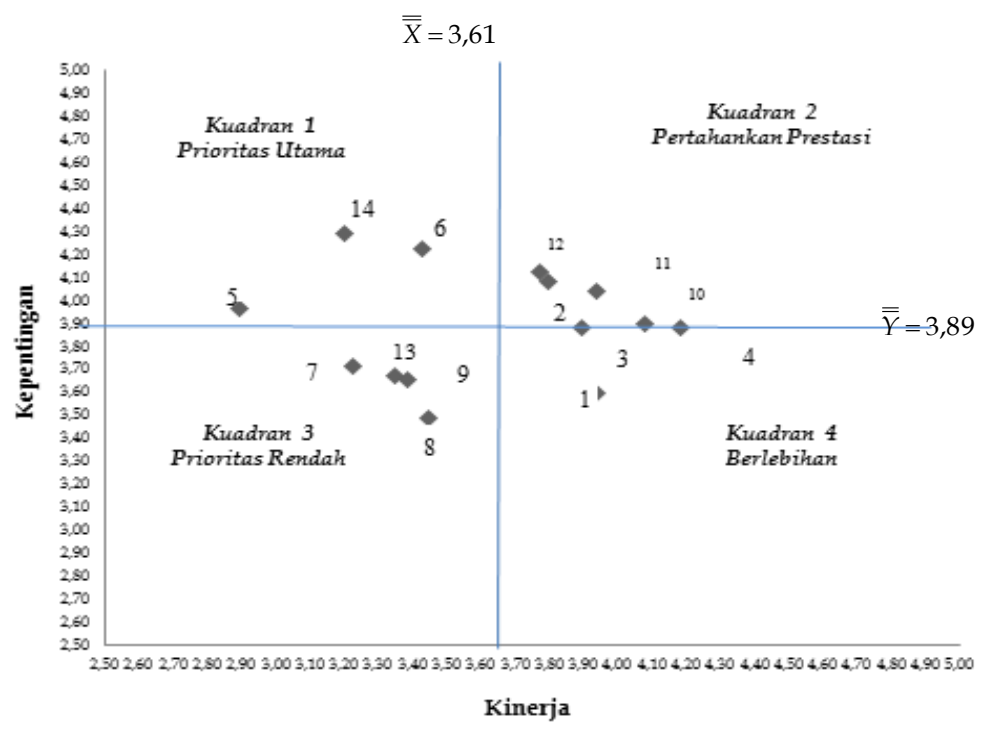

Gambar 3.

Diagram Kartesius Untuk Pengukuran Importance dan Performance Layanan Lembaga Pemasaran 2

Beberapa atribut yang penting dan perlu diprioritaskan tergambar pada kedua gambar tersebut yang meunjukkan kualitas layanan dari kedua lembaga. Selanjutnya untuk memperjelas poin-poin atributnya perlu dirangkum dalam tabel 3.

Aspek pelayanan lembaga pemasaran 1 (An. Bapak Ponimin) yang perlu ditingkatkan dan dianggap penting bagi petani diantaranya layanan yang cepat, tepat dan selalu tanggap membantu petani jagung, akurasi timbangan dan kesediaan petugas untuk menghargai dan melayani serta mengutamakan kebutuhan petani. Sedangkan aspek pelayanan lembaga pemasaran 2 (An. Bapak Kustur) yang perlu ditingkatkan dan dianggap penting bagi petani diantaranya penyampaian informasi kualitas jagung yang diinginkan konsumen kepada petani, kemampuan berkomunikasi dari petugas dan keterbukaan dan kejujuran dalam memberikan pelayanan informasi.

Dari tabel 3 dapat dilihat bahwa adanya perbedaan letak atribut dari masing-masing layanan lembaga pemasaran. Penilaian yang berbeda dari petani jagung yang bersangkutan serta layanan yang diberikan oleh masing-masing lembaga pemasaran menimbulkan perbedaat terhadap aspek-aspek tersebut. Disisi lain ada persamaan letak atribut pada suatu kuadran dari kedua layanan lembaga pemasaran yang menunjukkan bahwa adanya kualitas layanan yang hampir sama dari kedua lembaga pemasaran, serta penilaian yang sama dari petani jagung yang bersangkutan terhadap aspek-aspek tersebut.

54 Irvan Diyahya, Ketut Sukiyono dan Redy Badrudin, Analisis Tingkat ... 
Tabel 3. Atribut Layanan Lembaga Pemasaran Berdasarkan Prioritas)

\begin{tabular}{|c|c|}
\hline Lembaga Pemasaran 1 & Lembaga Pemasaran 2 \\
\hline \multicolumn{2}{|c|}{ Prioritas Utama } \\
\hline $\begin{array}{l}\text { 8. Pelayanan yang diberikan cepat, tepat dan } \\
\text { selalu tanggap membantu petani }\end{array}$ & $\begin{array}{l}\text { 5. Menyampaikan informasi kualitas jagung yang } \\
\text { diinginkan konsumen kepada petani }\end{array}$ \\
\hline $\begin{array}{l}\text { 12. Kekuratan timbangan saat melakukan } \\
\text { penimbangan jagung }\end{array}$ & 6. Kemampuan berkomunikasi dari petugas \\
\hline $\begin{array}{l}\text { 13. Kesediaan untuk menghargai dan melayani } \\
\text { serta mengutamakan kebutuhan petani }\end{array}$ & $\begin{array}{l}\text { 14. Keterbukaan dan kejujuran dalam memberikan } \\
\text { pelayanan informasi }\end{array}$ \\
\hline \multicolumn{2}{|c|}{ Pertahan Prestasi } \\
\hline 1. Kelengkapan sarana pengepakkan & $\begin{array}{l}\text { 2. Peralatan selama proses transaksi (kalkulator, } \\
\text { buku, pena, alat timbang dan lain-lain) }\end{array}$ \\
\hline $\begin{array}{l}\text { 2. Peralatan selama proses transaksi (kalkulator, } \\
\text { buku, pena, alat timbang dan lain-lain) }\end{array}$ & $\begin{array}{l}\text { 10. Ketepatan waktu dalam membayar jagung } \\
\text { yang dibelinya }\end{array}$ \\
\hline $\begin{array}{l}\text { 4. Adanya alat transpotasi yang digunakan untuk } \\
\text { memasarkan produk }\end{array}$ & $\begin{array}{l}\text { 11. Harga beli yang pantas/sesuai terhadap jagung } \\
\text { yang dibeli dari petani }\end{array}$ \\
\hline $\begin{array}{l}\text { 10. Ketepatan waktu dalam membayar jagung } \\
\text { yang dibelinya }\end{array}$ & $\begin{array}{l}\text { 12. Kekuratan timbangan saat melakukan } \\
\text { penimbangan jagung }\end{array}$ \\
\hline $\begin{array}{l}\text { 11. Harga beli yang pantas/sesuai terhadap jagung } \\
\text { yang dibeli dari petani }\end{array}$ & \\
\hline
\end{tabular}

\section{Prioritas Rendah}

5. Menyampaikan informasi kualitas jagung yang diinginkan konsumen kepada petani

7. Kemampuan petugas dalam membantu memberikan solusi atas keluhan petani dalam hal pemasaran jagung

7. Kemampuan petugas dalam membantu memberikan solusi atas keluhan petani dalam hal pemasaran jagung

9. Mampu menampung berapapun jagung yang dihasilkan dan akan dijual oleh petani

8. Pelayanan yang diberikan cepat, tepat dan selalu tanggap membantu petani jagung

9. Mampu menampung berapapun jagung yang dihasilkan dan akan dijual oleh petani

13. Kesediaan untuk menghargai dan melayani serta mengutamakan kebutuhan petani

3. Alat komunikasi yang dimiliki oleh petugas (telepon dan handphone)

6. Kemampuan berkomunikasi dari petugas

14. Keterbukaan dan kejujuran dalam memberikan pelayanan informasi

Sumber: hasil penelitian diolah(2015)
1. Kelengkapan sarana pengepakkan

3. Alat komunikasi yang dimiliki oleh petugas (telepon dan handphone)

4. Adanya alat transpotasi yang digunakan untuk memasarkan produk

\section{Tingkat Kepuasan Petani terhadap Layanan Lembaga Pemasaran dengan CSI}

Index kepuasan petani ini diperlukan karena hasil dari pengukuran dapat digunakan sebagai acuan untuk menentukan sasaran yang akan datang. Tanpa pengukuran ini, pihak lembaga pemasaran tidak dapat mengetahui apakah petani jagung puas atau tidak terhadap pelayanan yang diberikan. Tingkat 
kepuasan petani jagung terhadap layanan yang diberikan oleh kedua lembaga pemasaran disajikan pada tabel 4:

Tabel 4. Hasil perhitungan CSI untuk pelayanan lembaga pemasaran

\begin{tabular}{|c|c|c|c|c|c|c|c|c|}
\hline \multirow[t]{2}{*}{ No } & \multicolumn{4}{|c|}{ Lembaga Pemasaran 1} & \multicolumn{4}{|c|}{ Lembaga Pemasaran 2} \\
\hline & $(\bar{Y})$ & WF & $(\bar{X})$ & $(\mathrm{WS})$ & $(\bar{Y})$ & WF & $(\bar{X})$ & $(\mathrm{WS})$ \\
\hline 1 & 4.07 & 7.28 & 3.74 & 0.27 & 3.59 & 6.59 & 3.94 & 0.26 \\
\hline 2 & 4.14 & 7.41 & 3.63 & 0.27 & 4.08 & 7.49 & 3.80 & 0.28 \\
\hline 3 & 3.88 & 6.95 & 3.58 & 0.25 & 3.88 & 7.12 & 3.90 & 0.28 \\
\hline 4 & 4.28 & 7.66 & 3.77 & 0.29 & 3.88 & 7.12 & 4.18 & 0.30 \\
\hline 5 & 3.12 & 5.58 & 3.02 & 0.17 & 3.96 & 7.27 & 2.90 & 0.21 \\
\hline 6 & 3.88 & 6.95 & 3.56 & 0.25 & 4.22 & 7.75 & 3.43 & 0.27 \\
\hline 7 & 3.91 & 6.99 & 3.26 & 0.23 & 3.71 & 6.82 & 3.22 & 0.22 \\
\hline 8 & 4.12 & 7.37 & 3.40 & 0.25 & 3.49 & 6.40 & 3.45 & 0.22 \\
\hline 9 & 3.30 & 5.91 & 3.44 & 0.20 & 3.65 & 6.70 & 3.39 & 0.23 \\
\hline 10 & 4.37 & 7.82 & 3.53 & 0.28 & 3.90 & 7.15 & 4.08 & 0.29 \\
\hline 11 & 4.49 & 8.03 & 3.93 & 0.32 & 4.04 & 7.42 & 3.94 & 0.29 \\
\hline 12 & 4.47 & 7.99 & 3.44 & 0.28 & 4.12 & 7.57 & 3.78 & 0.29 \\
\hline 13 & 4.16 & 7.45 & 3.35 & 0.25 & 3.67 & 6.74 & 3.35 & 0.23 \\
\hline 14 & 3.70 & 6.62 & 3.63 & 0.24 & 4.29 & 7.87 & 3.20 & 0.25 \\
\hline$\sum$ & 55.88 & 100.00 & & 3.53 & 54,49 & 100.00 & & 3,61 \\
\hline \multicolumn{4}{|c|}{ Weighted Total (WT) } & & \multicolumn{3}{|c|}{ Weighted Total (WT) } & \\
\hline \multicolumn{4}{|c|}{ CSI $(\%)$} & 70.65 & CSI (\%) & & & 72,21 \\
\hline
\end{tabular}

Sumber: data primer diolah (2015)

Berdasarkan tabel 4 dapat dilihat bahwa hasil perhitungan CSI untuk aspek kualitas pelayanan lembaga pemasaran 1 adalah 70,65 \%. Sedangkan perhitungan CSI untuk aspek kualitas pelayanan lembaga pemasaran 2 adalah 72,21 \%. Hasil ini menandakan tingkat kepuasan petani terhadap dua lembaga pemasaran yang bersangkutan terletak antara selang $60 \%$ $\leq \mathrm{CSI} \leq 80 \%$. Dengan hasil ini, kedua lembaga pemasaran dapat menentukan langkah-langkah atau sasaran yang ingin dicapai selanjutnya agar petani jagung yang bersangkutan dapat merasakan lebih puas terhadap layanan yang diberikan oleh lembaga pemasarannya. Hal itu bisa dilihat berdasarkan perhitungan IPA dengan cara memperhatikan aspek-aspek dari masing-masing layanan-layanan mereka. Contohnya dengan melihat atribut-atribut yang masih memiliki nilai kinerja yang rendah namun dianggap penting oleh petani. Dengan ditingkatkan nilai kinerja akan meningkatkaan nilai Weighted Score sehingga akan meningkatkan nilai Customer Satisfaction Index. Dari data di atas dapat juga dilihat nilai Weighted Score dari kedua layanan lembaga pemasaran dimana nilai ini menunujukkan kontribusi dari atribut layanan lembaga pemasaran terhadap kepuasan petani secara keseliuruhan. Pada lembaga pemasaran 1, atribut yang mempunyai nilai Weighted Score tertinggi adalah untuk atribut nomor 11 (harga beli yang pantas/sesuai terhadap jagung yang dibeli dari petani). Sehingga atribut ini merupakan atribut yang memberikan 
kontribusi kepuasan tertinggi dibandingkan atribut-atribut lainnya dari layanan lembaga pemasan 1. Lembaga pemasaran 1 harus mempertahankan aspek ini karena aspek ini merupakan aspek yang penting bagi petani jagung. Berbeda pada kasus lembaga pemasaran 2 dimana nilai Weighted Score tertinggi diperoleh dari atribut nomor 4 (adanya alat transportasi yang digunakan untuk membeli produk). Pada kasus ini lembaga pemasaran 2 harus mempertahankan aspek ini karena apabila kinerjanya semakin menurun maka akan mempengaruhi kepuasan petani jagung yang bersangkutan.

Jadi apabila IPA dan CSI dihubungkan secara teori jelas bahwa nilai kinerja yang tinggi maka akan mempengaruhi kepuasan petani secara keseluruhan. Hal itu karena nilai kinerja merupakan pengali dari nilai Weighted Factor. Lembaga pemasaran harus segera meningkatkan atribut-atribut layanan yang masih memiliki kinerja yang rendah agar pelanggan mereka semakin merasa puas dan nyaman berhubungan dengan pedagangnya.

\section{SIMPULAN DAN SARAN}

\section{Simpulan}

Dari Importance Performance Analysis diperoleh kesimpulan bahwa aspek pelayanan lembaga pemasaran 1 (An. Bapak Ponimin) yang perlu ditingkatkan dan dianggap penting bagi petani diantaranya layanan yang cepat, tepat dan selalu tanggap membantu petani jagung, akurasi timbangan dan kesediaan petugas untuk menghargai dan melayani serta mengutamakan kebutuhan petani. Kemudian aspek pelayanan lembaga pemasaran 2 (An. Bapak Kustur) yang perlu ditingkatkan dan dianggap penting bagi petani diantaranya penyampaian informasi kualitas jagung yang diinginkan konsumen kepada petani, kemampuan berkomunikasi dari petugas dan keterbukaan dan kejujuran dalam memberikan pelayanan informasi. Berdasrakan kesimpulan ini terlihat ada harapan-harapan petani terhadap lembaga pemasaran yang belum terpenuhi selama ini.

Dari Customer Stisfaction Index diperoleh kesimpulan bahwa petani jagung merasa puas terhadap pelayanan lembaga pemasaran 1 (An. Bapak Ponimin) dengan CSI 70,65 \% dan puas terhadap pelayanan lembaga pemasaran 2 dengan CSI sebesar 72,21 \%. Secara keseluruhan tingkat kepuasan petani jagung terhadap pelayanan lembaga pemasaran terletak antara selang $61 \% \leq \mathrm{CSI} \leq 80 \%$ (kategori puas).

\section{Saran}

Berdasarkan kesimpulan di atas, peneliti memberi saran untuk kedua lembaga pemasaran agar memperhatikan aspek-aspek yang menjadi prioritas utama. Untuk lembaga pemasaran 1 agar meningkatkan kinerja item-item 
layanannya seperti layanan yang cepat, tepat dan selalu tanggap membantu petani jagung, akurasi alat timbang dan kesediaan petugas untuk menghargai dan melayani serta mengutamakan kebutuhan petani. Untuk lembaga pemasaran 2 agar meningkatkan kinerja item-item layanannya seperti penyampaian informasi kualitas jagung yang diinginkan konsumen kepada petani, kemampuan berkomunikasi dari petugas, keterbukaan dan kejujuran dalam memberikan pelayanan informasi. Kemudian peneliti selanjutnya agar mempertimbangkan aspek-aspek yang masih perlu diukur dari layanan lembaga pemasaran misalnya keramahan dari petugas dalam melayani petani. Kemudian penentuan aspek-aspek lainnya bisa disesuaikan dengan kondisi di lapangan.

\section{DARTAR PUSTAKA}

Bahua, M. I. 2014. Hubungan Karakteristik Petani Dengan Kompetensi Usahatani Jagung di Tiga Kecamatan di Kabupaten Pohuwato Fakultas Pertanian, Program Studi Agroteknologi, Universitas Negeri Gorontalo. (Skripsi).

Indriwinangsih. dan Sudaryanto. 2007. Pengukuran Kualitas Pelayanan Kartu

Pra Bayar Pro XL di Wilayah Depok. Jurnal Manajemen dan Pemasaran 1(7): 1 - 10.

Listiawati, I. 2010. Analisis Kepuasan Petani Terhadap Pelayanan Lembaga Penyuluhan di Desa Sukamahi Kecamatan Megamendung Kota Bogor. Jurnal IPB.

Nasution, M. N. 2001. Manejemen Mutu Terpadu. Penerbit Andi, Yogyakarta.

Rangkuti. 2006. Measuring Customer Satisfaction : Teknik Mengukur dan Strategi Menaikkan Kepuasan Pelanggan Plus Analisis Kasus PLN - JP. PT Gramedia Pustaka Utama, Jakarta.

Simamora. 2004. Panduan Riset Perilaku Konsumen. PT. Gramedia Pustaka Utama, Jakarta.

Stratford. 2004. http://www.Stratford.gof.uf/comunity/council-805.cfm.htm .Stratford on Avon District Council Costumer Statisfuction Indeks. ( Diakses Pada tanggal 11 November 2014)

Sukiyono, K. 2013. Penelitian Survey dan Teknik Sampling. Lab Sosial Ekonomi Pertanian UNIB, Bengkulu.

Supranto J. 2001. Pengukuran Tingkat Kepuasan Pelanggan. Bineka Cipta. Jakarta. Yola, M dan Budianto, D. 2013. Analisis Kepuasan Konsumen Terhadap Kualitas Pelayanan Dan Harga Produk Pada Supermarket Dengan Menggunakan Metode Importance Performance Analysis (IPA). Jurnal Optimasi Sistem Industri. 12(2):301309

58 | Irvan Diyahya, Ketut Sukiyono dan Redy Badrudin, Analisis Tingkat ... 